\title{
A corpus-based comparative study of Malaysian ESL learners and native English speakers in compliments patterns
}

\begin{abstract}
Even though many language learners are concerned with to master target proficiency, owing to years of meticulous studies, immersion in TL environments, access to multimedia and educational amenities, in addition to availability of affluent sources or merely thanks to Godgiven language talents, many will seldom take off from conspicuous learner-language and might never produce authentic language either in speech or in writing. In recent years, however, with corpus linguistics gaining currency in academia, a new light has begun to glimmer at the end of the tunnel that corpus-based materials and data-driven language instructions can actively and consciously engage learners and acquaint them with what authentic language is rather than what the text books prescribe it to be. Already, a growing body of research has been dedicated to data-driven learning across the world to survey the effectiveness of incorporating corpora in ELT. As such, the purpose of this research is to investigate the patterns of compliments in writings of the Malay ESL students and compare the findings with native English speakers. The results showed that the Malay ESL learners used a rather different number of syntactic patterns compared to the English native speakers and their frequency of patterns outgrew those of the natives.
\end{abstract}

Keyword: Compliment patterns; Corpora; Malaysian ESL learners; Native English speakers 